\title{
HAPPINESS AND THE NEED IN RELATEDNESS
}

\section{CHAIKA Galyna}

In Happiness And Contemporary Society : Conference Proceedings Volume (Lviv, March, 20-21, 2020). Lviv: SPOLOM, 2020. P. 52-54.

ISBN 978-966-919-593-7 


\section{CHAIKA Galyna \\ $\mathrm{PhD}$ in Psychology \\ G.S. Kostiuk Institute of Psychology of NAES of Ukraine (Kiev, Ukraine) \\ HAPPINESS AND THE NEED IN RELATEDNESS}

The modern Western European civilization relies on individualism, personal autonomy, which means that every person is valuable. Therefore, studies related to an individual's Self are very popular: self-realization, self-actualization, self-determination, self-attitude, self-consciousness, this series can be continued. Behind the scale of these studies it is somehow forgotten that people are, by their nature, social creatures, that is, they cannot exist without interactions with others, without a sense of support and emotional connection with friends or relatives, without feeling friendship or love to someone. Warm relationships with others, a sense of emotional closeness, support and understanding from the nearest and dearest are an important component of happiness.

In other words, every person from the birth needs to have some feeling of relatedness. This obvious, at first glance, idea was formulated at the scientific level in the 1950s by British psychoanalyst John Bowlby, the creator of Attachment Theory, (Cassidy, 1999). The attachment theory focuses mainly on the relationship between a mother and her baby. This is certainly an important topic, but attachment to others exists at all stages of an individual's life from birth to death. In essence, attachment means an individual's ability of a person to develop basic trust in him/herself and significant others. That is, each person seeks in his/her environment those who deserve to be trusted, and must have feelings, skills and knowledge (competences) that help understand that the other person is trustworthy. This creates and maintains mutually positive relationships. That is, every person is not as independent as it is believed by advocates of the view on personal autonomy as on an ultimate goal.

That is why, the developers of the self-determination theory, in addition to the need for autonomy, consider the equal need - the need in relatedness, which means an individual's desire to interact with, be connected to, and experience caring for others (Гордеева, 2006). C. Riff (1995), the developer of the six-factor model of psychological well-being, who stays on positions close to the authors of the self-determination theory, calls a positive relationship with others as one of the factors. High scores on this factor reflect the respondent's engagement in meaningful relationships with others that include reciprocal empathy, intimacy, and affection.

Relatedness means a sense of closeness based on deep sympathy, warm attitudes, commitment to someone. Awareness and acceptance of the natural need for relatedness means:

1. formation of proximity. Good relationships are impossible without a sense of secure emotional and physical closeness, and this feeling is possible with inner permission to feel affection, to reduce distance; 
2. development of trust. If we allow ourselves and our nearest and dearest to form a healthy attachment (not interdependence), we organize space for us together and space for each. This is a zone of trust in relationships;

3. a sense of security. Relatedness builds trust and closeness, which in turn gives us a sense of security in contact with another person.

The question arises as to what personal characteristics, qualities or factors contribute to establishing of trusting relationships, their support, generally contributing to the need in relatedness, in positive relationships with others, in a created real circle of loved ones. The author must say that there are almost no studies on this topic in the modern Ukrainian psychological science. There is only a certain statement that positive relationships with others are good, and there is a large amount of work devoted to the development of communicative abilities of both children and adults.

In foreign scientific literature, there are works that cover the problem of relatedness. Relatedness, in particular, seems to play a unique role in facilitating positive relationship functioning. However, it is important to note that relatedness is distinct from other, more general concepts of affect and self-view in relation to others. For instance, relatedness is not simply positive or negative affect, vitality, or from a sociometer perspective, self-esteem (Patrick et. al, 2007). The researchers also determined that when one feels that his or her needs in relatedness are being met, he or she experiences higher satisfaction, commitment, and employs more adaptive responses to conflict.

Other studies showed that people who experience higher relatedness expect future interactions to better fulfil their relatedness needs (Simpson et al, 2007). Individuals who report experiencing more relatedness also report valuing those feelings more and enjoying the experiences more deeply (Moller et al, 2010). These findings suggest that increased expectations for and value placed on relatedness may act as motivation to seek further relatedness experiences.

Pavey L et al. (2011) reasoned that relatedness need satisfaction is particularly important for promoting prosocial behaviour because of the increased sense of connectedness to others. Collins and Feeney (2014 also emphasize that accepting support when needed, and being willing and able to provide support in return, should cultivate the types of mutually caring relationships that enable people to thrive.

As we can see the presented works are focused on good emotion evoked by feeling of relatedness or make attempt to distinguish relatedness form other close concepts. The author cannot find studies describing personal characteristics that support development of positive relations with others or how such characteristics help fulfil the need in relatedness and, thus, promote the feeling of happiness. So, it would be interesting to perform research in the proposed field.

\section{REFERENCES}

1. Гордеева Т.О. Теория самодетерминации Э. Деси и Р. Райана / Психология мотиващии достижения. М.: Смысл; Издательский центр "Академия", 2006. 332 с.

2. Cassidy J. The Nature of a Child's Ties. / Cassidy J, Shaver PR (ed.). Handbook of Attachment: Theory, Research and Clinical Applications. New York: Guilford Press, 1999. P. 3-20. 
3. Collins N., Feeney B. A New Look at Social Support: A Theoretical Perspective on Thriving Through Relationships. / Personality and Social Psychology Review, October, 2014. doi:10.1177/1088868314544222.

4. Moller A.C., Deci E.L., Elliot A.J.. Person-level relatedness and the incremental value of relating. Personality and Social Psychology Bulletin, 2010. V.36. P. 754-767. doi:10.1177/0146167210371622

5. Patrick. H., Knee. C.R., Canevello A., Lonsbary, C. The role of need fulfillment in relationship functioning and well-being: A self-determination theory perspective. Journal of Personality and Social Psychology, 2007. V. 92, P.434-457. doi:10.1037/00223514.92.3.434

6. Pavey L., Greitemeyer T., Sparks P. Highlighting relatedness promotes prosocial motives and behavior. Personality and Social Psychology Bulletin, 2011. No 37(7), P. 905-917. https://doi.org/10.1177/0146167211405994

7. Ryff, C. (1995). The structure of psychological well-being revisited. Journal of Personality and Social Psychology. No 69, 719-727.

8. Simpson J.A., Collins W.A., Tran S., Haydon, K.C. Attachment and the experience and expression of emotions in romantic relationships: A developmental perspective. Journal of Personality and Social Psychology, 2007. V.92, P. 355-367. doi:10.1037/00223514.92.2.355 